\title{
山崎断層系大原断層のトレンチ調査
}

\author{
（助）電力中央研究所地質地盤部* 遠 田 晋 次 - 宮 腰 勝 義・井上大 栄 \\ 楠 建一郎・鈴木 浩一
}

\section{Trench Survey for the Ohara Fault of the Yamasaki Fault System at Hurumachi, Ohara Town, Okayama Pref., Japan}

\author{
Shinji Toda, Katsuyoshi Mryakoshi, Daiei Inoue, \\ Ken'ichiro Kusunoki and Koichi Suzuki

\begin{abstract}
Department of Geology and Geotechnology, Central Research Institute of Electric Power Industry,
\end{abstract} \\ 1646 Abiko, Abiko, Chiba, 270-11, Japan
}

(Received August 12, 1994; Accepted January 5, 1995)

\begin{abstract}
The Yamasaki fault system is located from the eastern Okayama to Hyogo Prefectures, southwest Japan, trending in NW-SE direction with a length of 87 kilometers. Earthquake risk evaluation of this fault system is not complete because the past seismic events have not been determined throughout the fault system. This paper reports a comprehensive survey of the Ohara fault, located at the northwestern end of the fault system. High resolution electrical exploration and five drillings at Ohara Town clearly identified the location of the fault underneath the sediment cover. Trench survey was then carried out to determine the past seismic events along the Ohara fault. The following conclusions were derived from these studies. (1) The Ohara fault shows up as a sharp resistivity contrast in the high resolution electrical exploration, reflecting mainly the difference in resistivity between acid tuff and black slate that constitute the northern and southern sides of the fault, respectively. (2) The trench observation in the log and radiocarbon dating of sediments revealed that the latest fault movement along the Ohara fault occurred between 150 and 1200 years B.P. The Harima Earthquake of 868 years $\mathrm{AD}$ is most likely to correspond to this fault movement. The timing of the event roughly coincides with the latest event of the Yasutomi fault (Okada et al., 1987) comprising the central part of the Yamasaki fault system. This strongly suggests that the Ohara and Yasutomi faults ruptured simultaneously or as a sequence of events during the Harima Earthquake. (3) The penultimate movement of the Ohara fault was estimated between 1500 and 3000 years B.P. If the latest event corresponds to the Harima Earthquake, then the interval between the last two events is estimated to be 400 to 1900 years. (4) The present trench survey revealed possibly four events along the Ohara fault during the Holocene. Thus the recurrence interval may be about 2500 years. Comparing this result with the interval between the last two events, movement of this fault system is likely to be aperiodic.
\end{abstract}

Key words: Trench survey, Yamasaki fault system, Ohara fault, Harima earthquake, Multiple event.

\section{§1.はじめに}

山崎断層系は，岡山県勝田町から兵庫県加古川中流部 にかけて北西-南東に分布する全長 $87 \mathrm{~km}$ の断層系であ る.この断層系は断層線の連続性に基づき, 北西側から,

* ₹270-11 千葉県我孫子市我棌子 1640
大原断首 $(34 \mathrm{~km})$, 土方断層 $(18 \mathrm{~km})$, 安富断首 $(18$ $\mathrm{km})$, 碁坂峠断層 $(18 \mathrm{~km})$, 琵琶甲断層 $(10 \mathrm{~km})$, 三木断 層 $(22 \mathrm{~km})$ の 6 つのセグメントに分けられ, 活動度が B 〜C 級とされている [活断層研究会 (1991)]. 山崎断層系は, ほぼ全域にわたって左横ずれを示す河 川の屈曲が認められ, 多くの研究者によって詳細に記載 
されている [例えば, 松田・岡田 (1968)]. 特に断層系中 央部約 $50 \mathrm{~km}$ では, 100 万年前から現在までの間に 50 〜200 $\mathrm{m}$ 程度の左横ずれ水平变位を行なっているとさ れている [池辺・他 (1969)].

山崎断層系のうち安富断層については, 岡田・他 (1987)によってトレンチ調查が実施され, 最新活動時期 として西暦 868 年に播磨地域一帯に被害をもたらした と考えられている播磨地震 $(M \geqq 7.0)$ の可能性が示唆さ れている. しかしながら, 山崎断層系を構成する他のセ グメントが同時に活動したとする証拠は得られておら ず, 播磨地震の性格を知り将来考えられる地震の規模を 予測するうえでも他のセグメントの最新活動時期を明ら かにする必要がある.

今回著者らは, 山崎断層系の北西部を構成する大原断 層について, 活動史を明かにするため, 岡山県英田郡大 原町古町地区においてトレンチ調查を行なった (Fig. 1)。 その結果に基づき, 山崎断層系大原断首の最近の活動性 と山崎断層系のセグメンテーションについて議論する.

\section{§2. 大原断層の位置}

\section{1 大原町古町地区周辺の変位地形と地兵}

本調查地域および山崎断層系の变位地形は, 福井 (1981) が詳述している.また，地質は神戸・広川 (1963) において詳しい.ここでは, 変位地形と地質の概要につ いて記し, トレンチ調查地点周辺の地質状況と予想され る断層破哗帯の幅について述べる.

トレンチ調査地点から大原町西町地区にかけては西北 西一東南東に顕著な断層線谷が認められる.この断層線 谷に向かって小河川が流入しているが，それらには特に 左横ずれ変位は認められない。この断層線谷から吉野川 を挟んで北西側では, 変位地形が丘陵尾根上の鞍部とし て表現され，断層線は若干北に向きを変え北西一南東の 走向を示す. Fig. 1 に示されるように，そこでは 1 次谷 である 4 つの小河谷が左横ずれを示す系統的な屈曲を 示している[福井 (1981)]. そして, 大まかには, 上流域 が長いほど屈曲量が大きい傾向が認められる。

調查地点周辺の地質図を Fig. 2 に示す. 見掛け上, 中-古生界が $3 \sim 4 \mathrm{~km}$ の右横ずれ変位を示している.こ れは最近の左横ずれ断層運動と異なる.

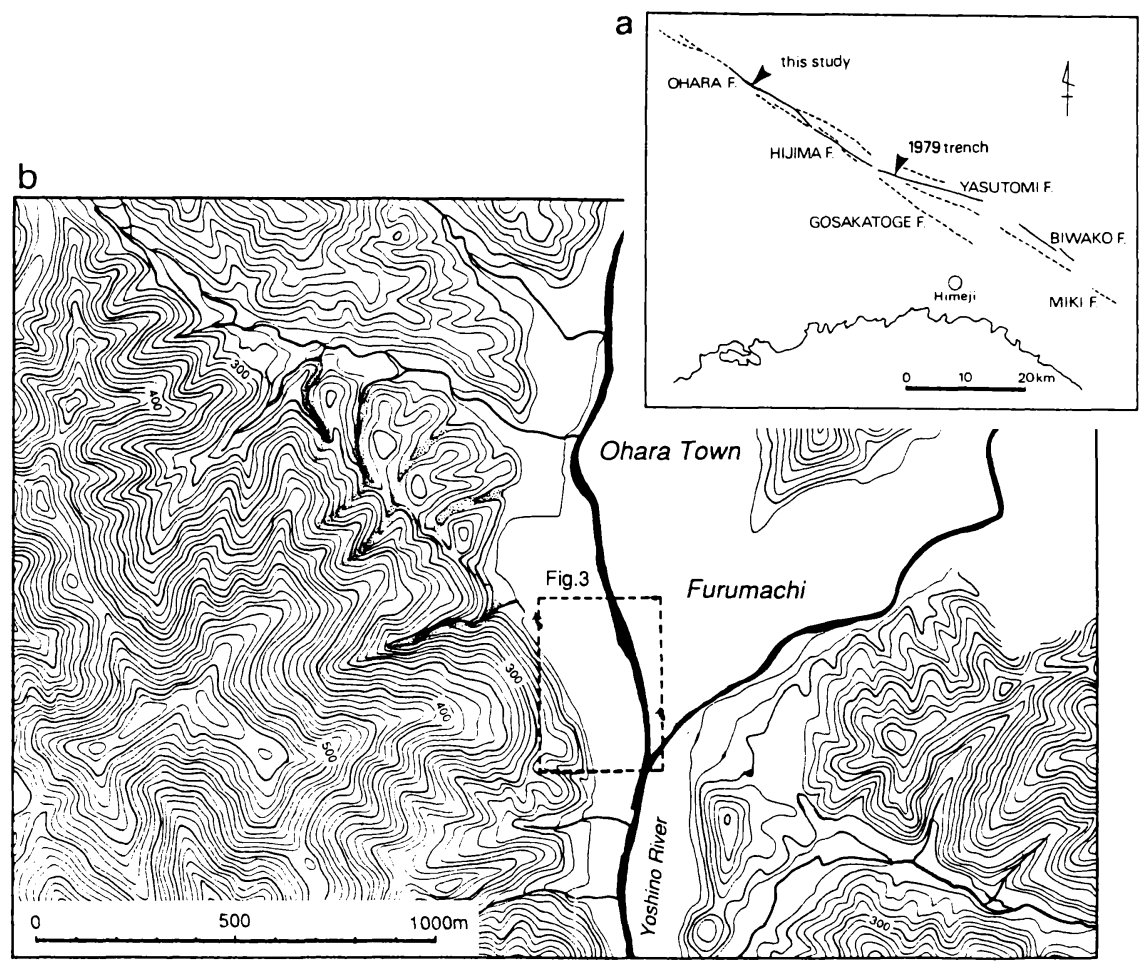

Fig. 1. (a) Distribution of the Yamasaki fault system. ОкаDA et al. (1987) carried out the trench study across the Yasutomi fault in 1979. (b) Displaced landforms along the Ohara fault around the Ohara Town. Stream channels are offset lefterally along the fault trace of the Ohara fault. This study was carried out at the western bank of the Yoshino river (Fig. 3). 


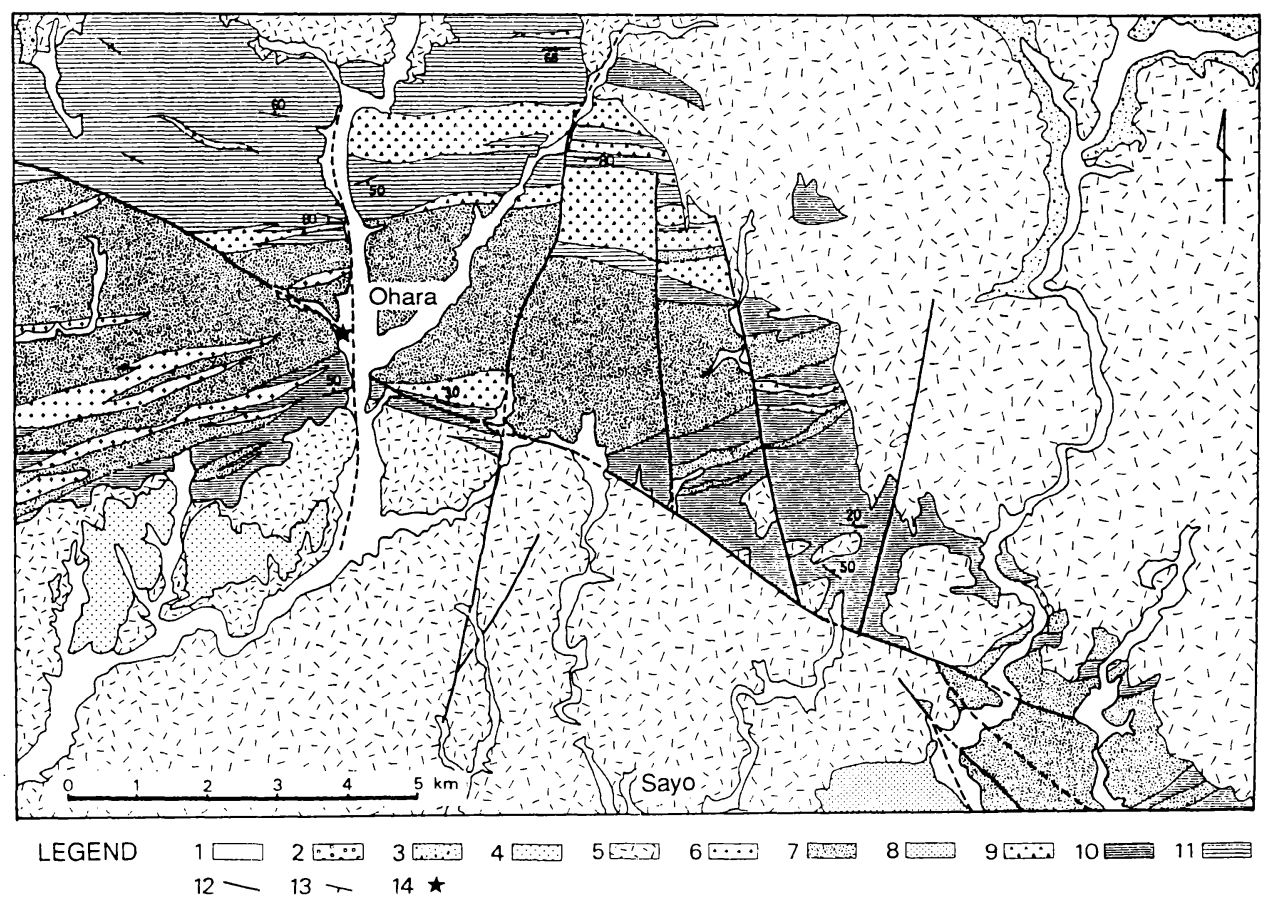

Fig. 2. Geological map around the Ohara fault [modified from KовE and Hiroкawa (1963)]. Legend shows 1: alluvial deposits, 2: terrace deposits, 3: talus deposits, 4: Neogene sedimentary rocks, 5: Cretaceous volcanic rocks, 6: Mesozoic to Paleozoic granodiorite, 7: Mesozoic to Paleozoic gabbro, 8: Mesozoic sandstone and slate, 9: Mesozoic slate, sandstone, chert and diabase, 10: Permian slate, sandstone, chert, limestome and diabase, 11: Paleozoic phyllite, diabase, chert and limestone, 12: fault, 13: dip and strike, 14: trench site. Note that the Paleozoic and Mesozoic formation had been offset right-laterally by the Ohara fault in the opposite sense to the left-lateral displacement in the Quaternary.

トレンチ調查を実施するに際して, 基盤の地質構造や 主断首と並走する断首の有無, 断層角磁・断層ガウジな ぞの破砕帯の幅・性状などを明かにしておく必要があ る. 今回の調查では, 調查地点周辺の基盤の破砕帯の幅 とその性状を把握するために，断層谷および鞍部周辺を 調査した，すなわち，断層線を挟んだ両側の地質の違い を把握するとともに各露頭で見られた基盤の破砕の程度 を松田・岡田 (1968) の断層破砕帯の破砕度を参考に記 載した。その結果, トレンチ調查地点周辺では神戸・広 川 (1963) に示されるように, 大原断層が疑灰岩（北側） と粘板岩（南側）の地質境界になっている可能性が強い ことと, 周辺の露頭には破砕度 II 以上の断層破砕帯は認 められず大原断層における断首破砕帯は数 $10 \mathrm{~m}$ オー ダー以下のかなり狭いものであることが推定された。

\section{2 高密度正気探查}

一般にトレンチ調查により最近の活動性を解読するに は, 年代の測定可能な沖積層が厚く堆積している地域が 望ましい，その場合, 断層変位速度に比べて堆積速度や
侵食速度が大きい地域では変位地形が保存されにくいた めに, 周辺の地形・地質情報のみからトレンチでカバー できる数 $10 \mathrm{~m}$ の調查範囲に断首位置を把握するのは難 しい. そのため, これまでにもいくつかの地点で, トレ ンチ調査に先だって, 詳細な断層位置解明のための物理 探查や化学挆查が実施され，その有用性が検討されてき た [例えば, 内田・他 (1984)].

今回の調查では, 調查地点を新期の堆積物の存在が予 想される吉野川右岸 (Fig. 1) に予定し，そこでまず高密 度電気探查によって断層位置の推定をおこなった。

高密度電気探査は, 原理的には従来の電気探査法之同 じであるが, 測定点をできるだけ高密度に配置して見掛 け比抵抗を測定し， 2 次元インバージョン解析を行ない 地下断面の情報を得るものである.

測定機器仕様, 測線之電極配列を Table 1, Table 2 に それぞれ示す. また, 電極はFig. 3 に示す測線で展開し た. なお, 測線 EA1,EA3 は水田脇の畦道を, EA2 は吉 野川左岸を利用して実施した。測線 EA2 は EA1, EA3 
Table 1. A summary of the system for the high resolution electrical exploration.

\begin{tabular}{|c|c|c|c|}
\hline Contents & Measures (types) & & Volume \\
\hline \multirow{9}{*}{$\begin{array}{l}\text { Measurement device } \\
\text { for electrical exploration }\end{array}$} & МсонМ & & 1 \\
\hline & Output voltage & $400 \mathrm{Vp}-\mathrm{p}$ & \\
\hline & Output electric current & $1 \sim 200 \mathrm{~mA}$ & \\
\hline & Action voltage & $12 \vee D C$ & \\
\hline & Cycle time & $3.5 \mathrm{sec}$ & \\
\hline & Data memories & 2000 data (max) & \\
\hline & Interlace & RS232C & \\
\hline & Scale & $206 \times 281 \times 200 \mathrm{~mm}$ & \\
\hline & Weight & about $7.5 \mathrm{~kg}$ & \\
\hline \multirow[t]{3}{*}{ Switch box } & 60 channels & & 1 \\
\hline & Scale & $206 \times 281 \times 200 \mathrm{~mm}$ & \\
\hline & Weight & about $5.3 \mathrm{~kg}$ & \\
\hline Personal computer & PC-286LE (16bit) & & 1 \\
\hline Electrode bar & c $15 \times 300 \mathrm{~mm}$ & & 60 \\
\hline Code & 60 channels & & 1 \\
\hline
\end{tabular}

Table 2. Electrode configuration for the high resolution electrical exploration.

\begin{tabular}{ccl}
\hline Survey line & Length $(\mathrm{m})$ & Electrode configuration \\
\hline EA-1 & 250 & 51 electrodes, $5 \mathrm{~m}$ interval (wenner, eltran) \\
EA-2 & 250 & 51 electrodes, $5 \mathrm{~m}$ interval (wenner, eltran) \\
EA-3 & 190 & 39 electrodes, $5 \mathrm{~m}$ interval (wenner, eltran) \\
\hline
\end{tabular}

に比べて約 $5 \mathrm{~m}$ 低い位置にあり吉野川河床では部分的 に基盤が露出していることから，測線 EA2では河床砂 砂が薄く覆うだけで堆積物はほとんど存在していない。

挆查結果を Fig. 4 に示す.それぞれの比抵抗断面図に 認められた顕著な比抵抗境界を E1〜E3 として示した。 3 つの比抵抗断面に共通して認められる特徴は, 中〜高 角度で北に傾斜する比抵抗境界によって北側に低比抵抗 部, 南側に高比抵抗部と明瞭に分けられることである.

また, 測線 EA1 と EA3 の比抵抗断面には深度 13〜15 $\mathrm{m}$ 以浅に約 $300 \Omega \mathrm{m}$ 以上の高比抵抗值を示す水平な比 抵抗層が存在する.

地層の比抵抗值は組成鉱物や，その結晶度・固結度・ 孔隙率などにより異なるほか，孔隙に含まれる水の量 と，その水質とによって著しく左右される．特に，孔隙 率への依存度は大きい [志村 (1964)]. したがって一般 には，1) 緻密な花䬏岩や各種の火山岩は孔陌率の高い堆 積岩類よりも比抵抗值が低いこと，2）破砕度が高く粘土 化するほど含水比が高くなるので比抵抗値が低いこと,

3) 地下水面下では地下水面上ょり比抵抗值が低いこと などがいえる。これまでのいくつかの地質と比抵抗值に 関する研究により，これらの解釈が断首近傍の地質構造 にも適用できることが実証されている [例えば, 楠・本

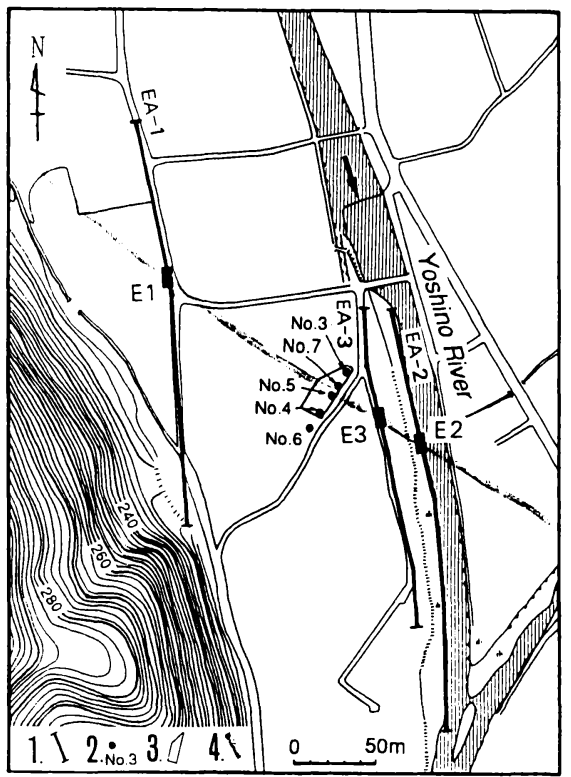

Fig. 3. Survey lines of the high resolution electrical exploration and locations of bore holes and the trench. Legend shows 1: survey line, 2: bore hole, 3 : trench, 4 : fault trace estimated from displaced landforms. $\mathrm{E} 1, \mathrm{E} 2$ and E3 are the most marked resistiv. ity gaps shown in Fig. 4.

\section{荘 (1990)]。}

これらに基づき，以下に地下構造を考察する.

前述の 3 つの比抵抗境界 (E1〜E3) は，これらをつな いだトレンドが Fig. 1 のように北西一南東を示し，変位 地形等により推定される断層位置の延長とほぼ一致す る. また，それぞれの比抵抗値を比較しても 3 測線とも 同様の地質構造をとらえているすのと考えられる。した がって，ここでは 2 とおりの解釈が可能である。 つま り, 1) 北側の低比抵抗帯が幅広い断層破砕帯で南側が非 破砕部の高比抵抗帯となっている場合，2）断層を挟んで 異なる岩相が接している場合である．前述した神戸・広 川 (1963) による地質構造と周辺の基盤の露出状況から, 大局的には断層を挟んで北側に中古生界の火山岩類（凝 灰岩）之南側に古生界二睍系の粘板岩が分布しており, ここでの比抵抗境界は岩相境界としての大原断層を表し ている可能性が強い，ちなみに，この推定は後述する ボーリング調查結果により検証されたが, それぞれの比 抵抗值の実測值として, ボーリング孔における電気検層 およびトレンチ法面での比抵抗測定から, 北側の凝灰岩

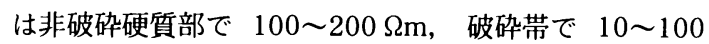
$\Omega \mathrm{m}$ を示し, 南側の粘板岩は非破砕硬質部で 400 800 $\Omega \mathrm{m}$, 破砕帯で 60 300 $\mathrm{m}$ を示すことが確認された。 
N

electrodes interval : $5 \mathrm{~m}$
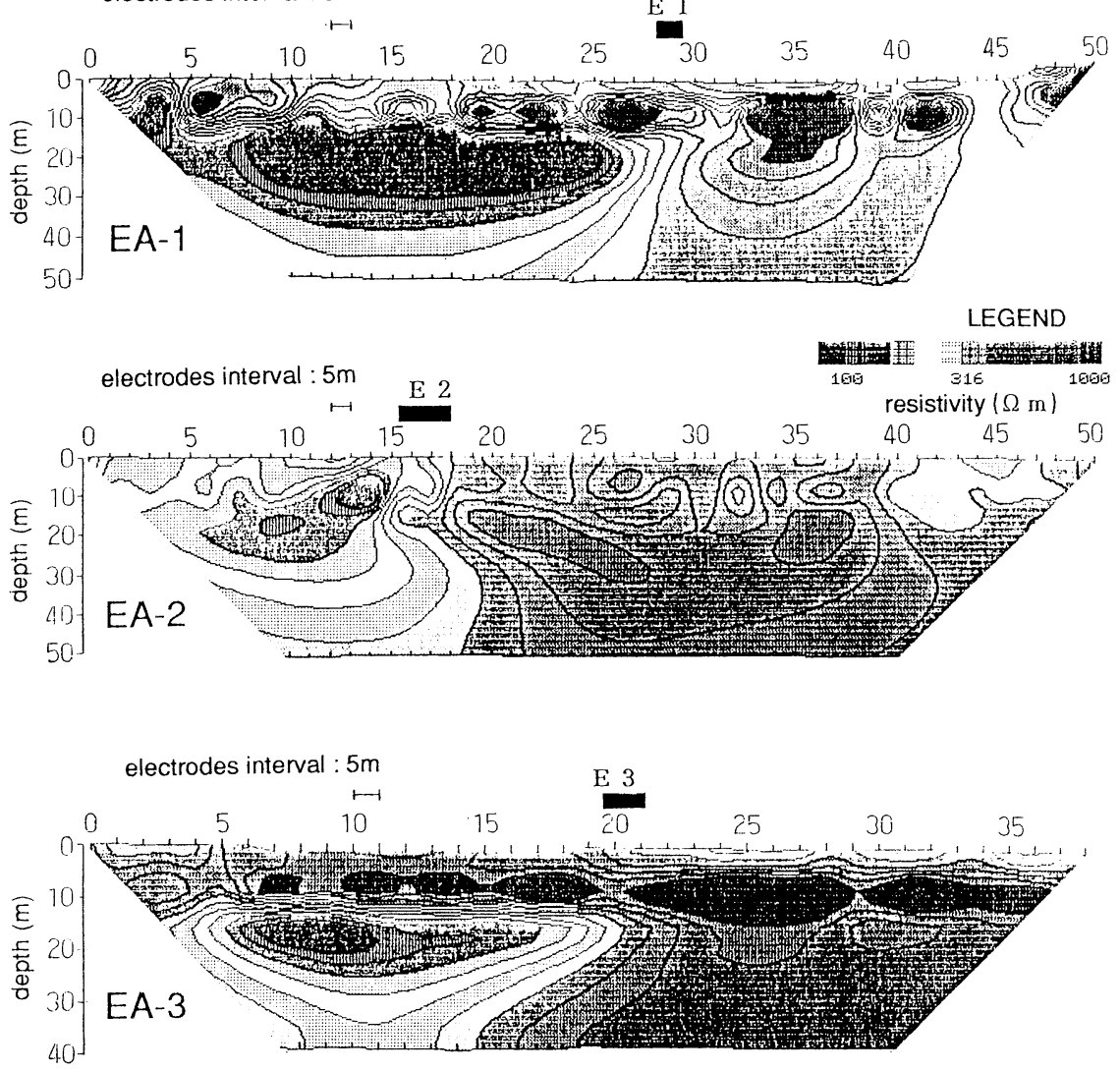

Fig. 4. Resistivity profiles determined by the high resolution electrical exploration. E1, E2 and E3 are the most marked resistivity gaps. Low resistivity on the northern side and high resistivity on the southern side correspond with tuff and slate, respectively.

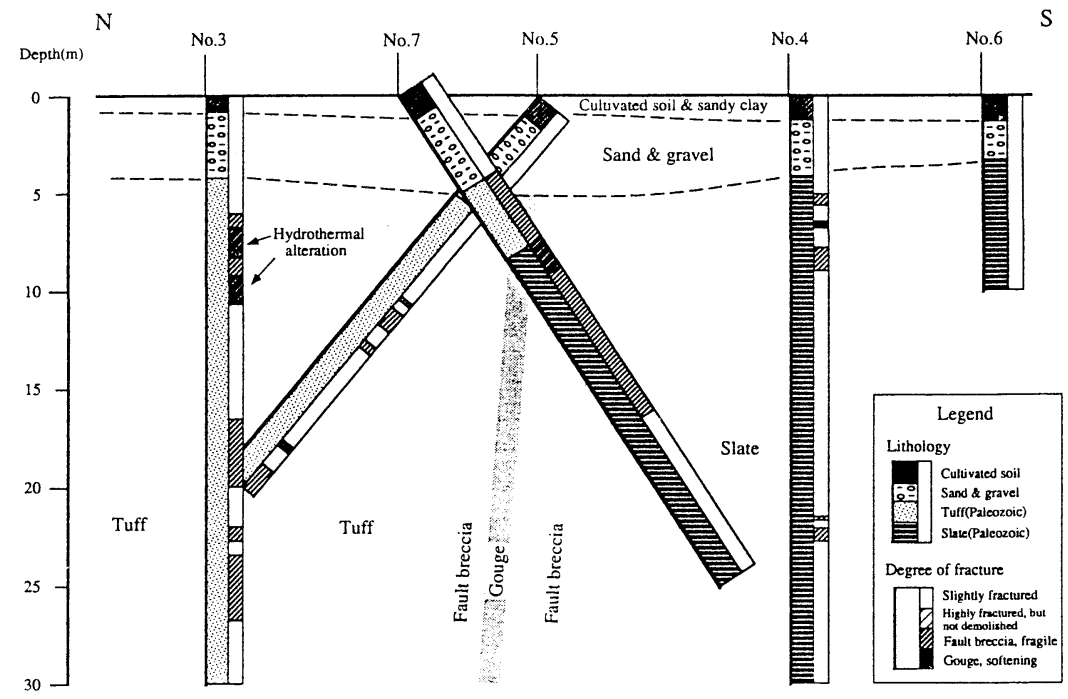

Fig. 5. Geological columns of bore holes and geological section. Fault gouge of $1.5 \mathrm{~m}$ in width, associated with the Ohara fault, was recognized near the top of the No. 5 bore hole. 


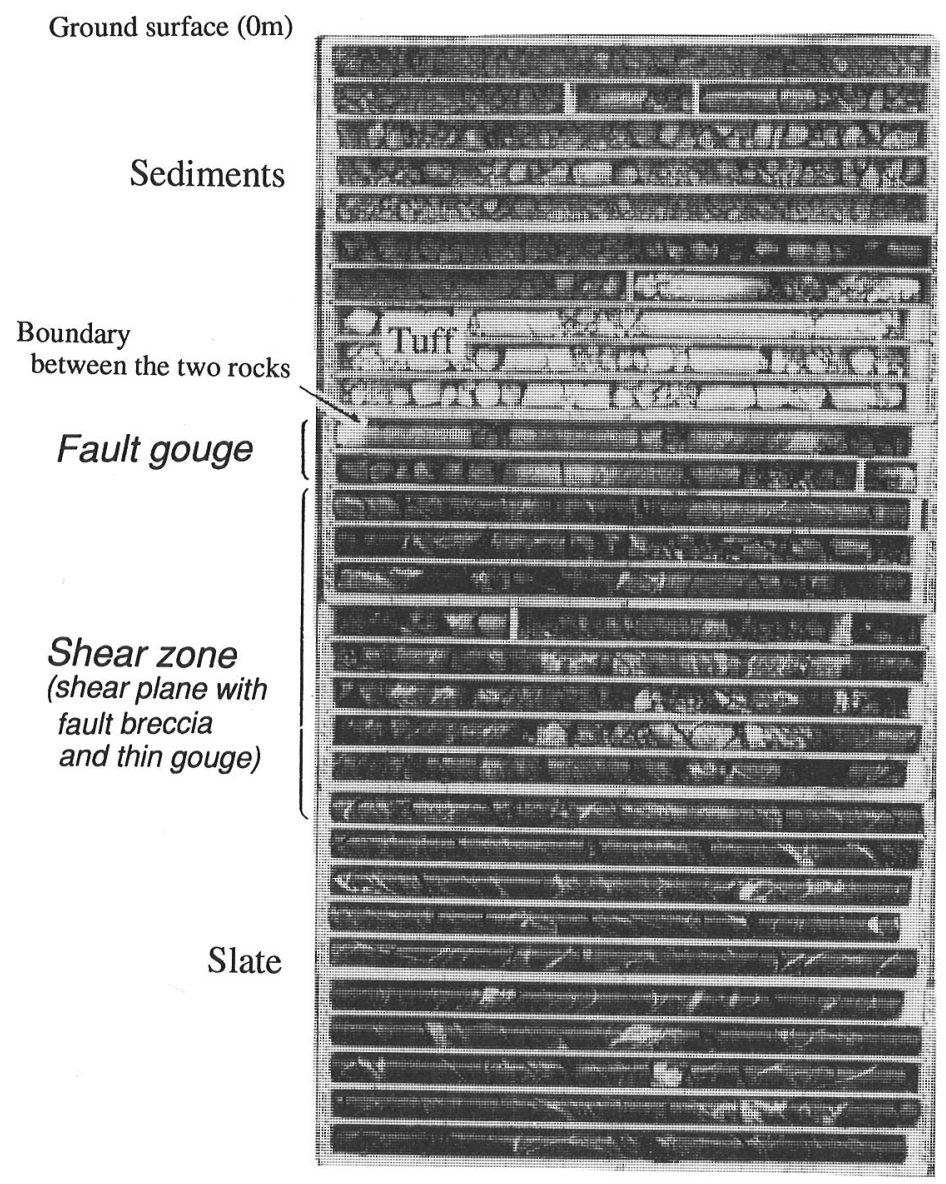

Fig. 6. Cores of the No. 7 hole, revealing the formation of the fault gouge of the Ohara fault at the boundary between tuff and slate.

また, EA1 とEA3 の比抵抗断面図にみられる浅部の水 平な高比抵抗層は基盤の露出する $\mathrm{EA} 2$ 測線に見られな いことから新期の堆積物を示すと考えられるが, 推定さ れる層厚はせいぜい $5 \mathrm{~m}$ 前後であり, 13〜15 $\mathrm{m}$ の深度 にその境界が現われている理由は不明である。なお， ボーリング調查時に認められた地下水位は地表下 $2.3 \mathrm{~m}$ であり，地下水の影響ではないことは明らかである.

\section{§3. ボーリング調查}

新期の堆積物の層厚と基盤の地質および破砕状況等を 調べるため, 電気探查結果によって推定された断層位置 周辺にボーリングを掘削した（掘削位置を Fig. 3 に示 す).なお，No. 5 と No. 7 は断層を直接貫く目的で，そ れぞれ北東に $57^{\circ}$, 南東に $50^{\circ}$ 傾斜させて掘削した。 そ れらの柱状図および推定断面図を Fig. 5 に示す.

コアの観察から, 新期の堆積物として耕作土および砂
質粘土, 泥質砂碩層が $3.3 \mathrm{~m} \sim 5.1 \mathrm{~m}$ の層厚で分布して おり, 基盤はNo. 5 孔付近を境に北側が珪質な灰白色凝 灰岩, 南側が黒色粘板岩であることがわかった。

堆積物は，基盤の岩相境界である No. 5 孔付近が最も 厚く約 $5 \mathrm{~m}$ で, 南側, 北側に, 徐々に薄くなる. しかし ながら, ボーリングコアが乱されていたため, 得られた コアからは泥質砂碩層の中の詳細な地層区分を充分行な うことができず, 被覆層中の断層面を確認することはで きなかった。

基盤の断層付近での岩相や破研状況の変化は, No. 7 孔において詳細に把握できた (Fig. 6). 以下に, その記載 を示す.

No. 7 孔斜長 $6.0 \sim 10.05 \mathrm{~m}$ は, 灰白色の酸性凝灰岩で あり, 全体的に変質作用を被りやや脆弱で, 部分的に粘 土状〜小角礫状を呈していた．黑色粘板岩中の岩相境界 付近の斜長 10.05 11.8 m の部分は, 軟弱で鏡肌が顕著 


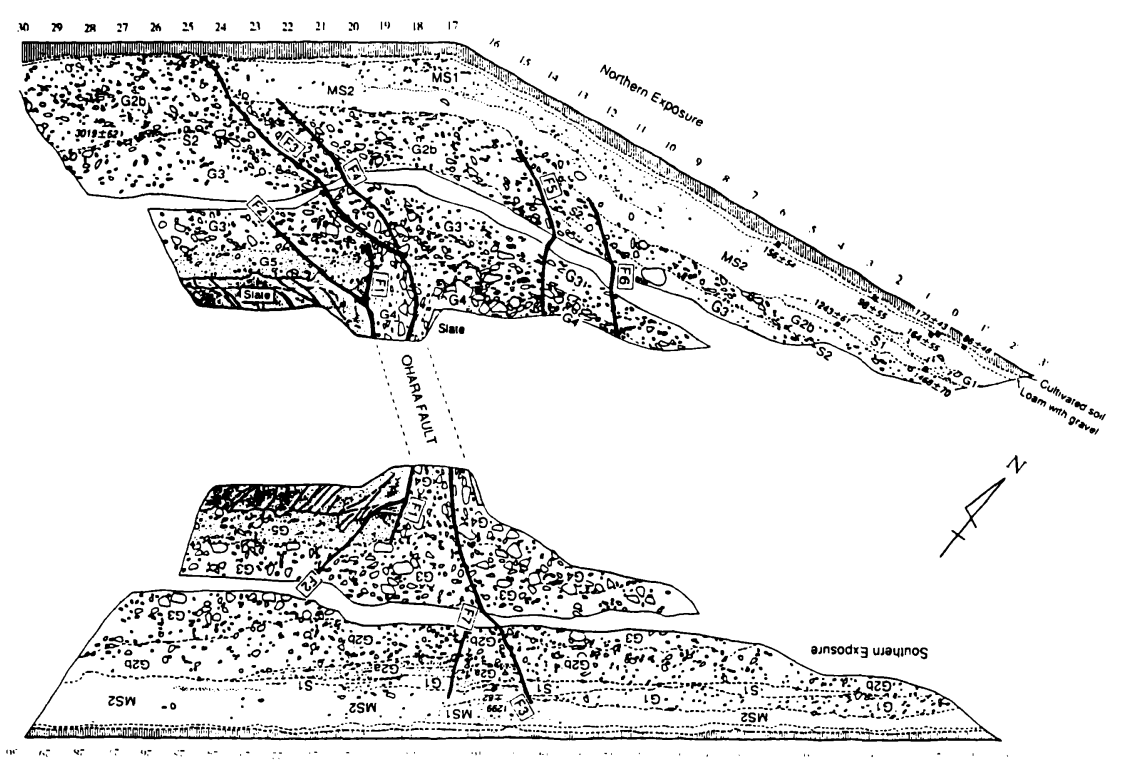

Fig. 7. A sketch of the trench. Several beds marked like MS1, MS2, etc, were distinguished by means of the difference of the constitutional material and grain size. Charcoal samples for ${ }^{14} \mathrm{C}$ dating were collected at some horizons indicating square plots with radiocarbon ages (years B. P.). They are also shown in Fig. 8 and Table 3. Seven faults (F1 to F7) were recognized in sediments.

な断首ガウジとなっており新期の活動が予想される.コ アに見られる断層面の傾斜から，断層ガウジの幅は約 $1.5 \mathrm{~m}$ と考えられる. この断層ガウジは，北側の約 25 $\mathrm{cm}$ は橙〜褐色に風化が進んでいるが, 風化面上に明瞭 な条線が残されていることから, 比較的新しい時期に活 動したことが予想される.

No. 7 孔斜長 $11.8 \sim 20.6 \mathrm{~m}$ では, 黒色粘板岩が部分的 に破砕されており, 剝離状を呈す脆弱部之白色脈の多い 短柱状コアが混在している，剪断面は固結したものが多 く, 軟弱な断層ガウジはほとんど挟んでいない。この部 分より南西側のコアは, 新鮮・硬質で断層運動による破 砕の影響を全く受けていない。

\section{§4. トレンチ調查}

上述の高密度電気探査結果とボーリング調査結果か

ら,トレンチ掘削位置を No. 3 孔と No. 4 孔の間に設定 し, Fig. 3 に示すようなトレンチを掘削した. なお, 基 盤中の断層を確認するための最深部の掘削は, 法面の安 定性を考慮して, 埋め戻し直前に行なった。

トレンチ法面のスケッチを Fig. 7 に, 模式地質柱状図 を Fig. 8 に，模式地首区分および砅のファブリックを Fig. 9 に示す.

基盤の断首は前述の調査により予想された位置に認め られ, 新期の堆積物中にもいくつかの断層が見られた。 以下にトレンチ内の地層と断層について述べる.

\section{1 トレンチ内の地犋}

トレンチ内では, ボーリング調査時に記載したものよ りも多くの地層の識別が可能であり, それらは複数の断 層によって明瞭に变位していた．以下にトレンチ内の地 層の特徵について上位のものから詳しく述べる.

1. 耕作土：本首は, 地表下 $30 \mathrm{~cm}$ までで, トレンチ 内全法面にほぼ等しい厚さで見られる。

2. 砂碟混じりローム：本首は，橙色を呈す $1 \mathrm{~cm}$ 以 下の脆い軽石之同質の基質から構成され, 部分的に細磁 および砂を多く含む. 層厚は約 $20 \mathrm{~cm}$ 前後でトレンチ 内全法面にほぼ等しい厚さで見られる. 周辺にこのよう なローム層が認められないことから, 耕作土直下に軽石 を人工的に敷き詰めた可能性むある。

3. 磁混じり褐色泥質砂層 (MS1)・褐色泥質砂首 (MS2): 本層は, 主として無層理塊状の褐色を呈す比較 的密な泥質の細〜中粒砂からなる. 北側, 南側法面のそ れぞれ中央部では, 円磨された細〜中砂を多く含む部分 が認められ，それらは碩混じり褐色泥質砂層 (MS1) とし て, 褐色泥質砂首 (MS2) と区別した.

本層は, 一般的な河川堆積物とは考えにくく，いわゆ る“フラッドローム（洪水直後の細粒堆積物, 火山灰起 源のロームではない)”の可能性が強い. 上部の MS1 は, その分布と後述する断層との関係から，断層活動に よって生じた凹地に周辺から磂があたらされて形成され たと考えられる。 


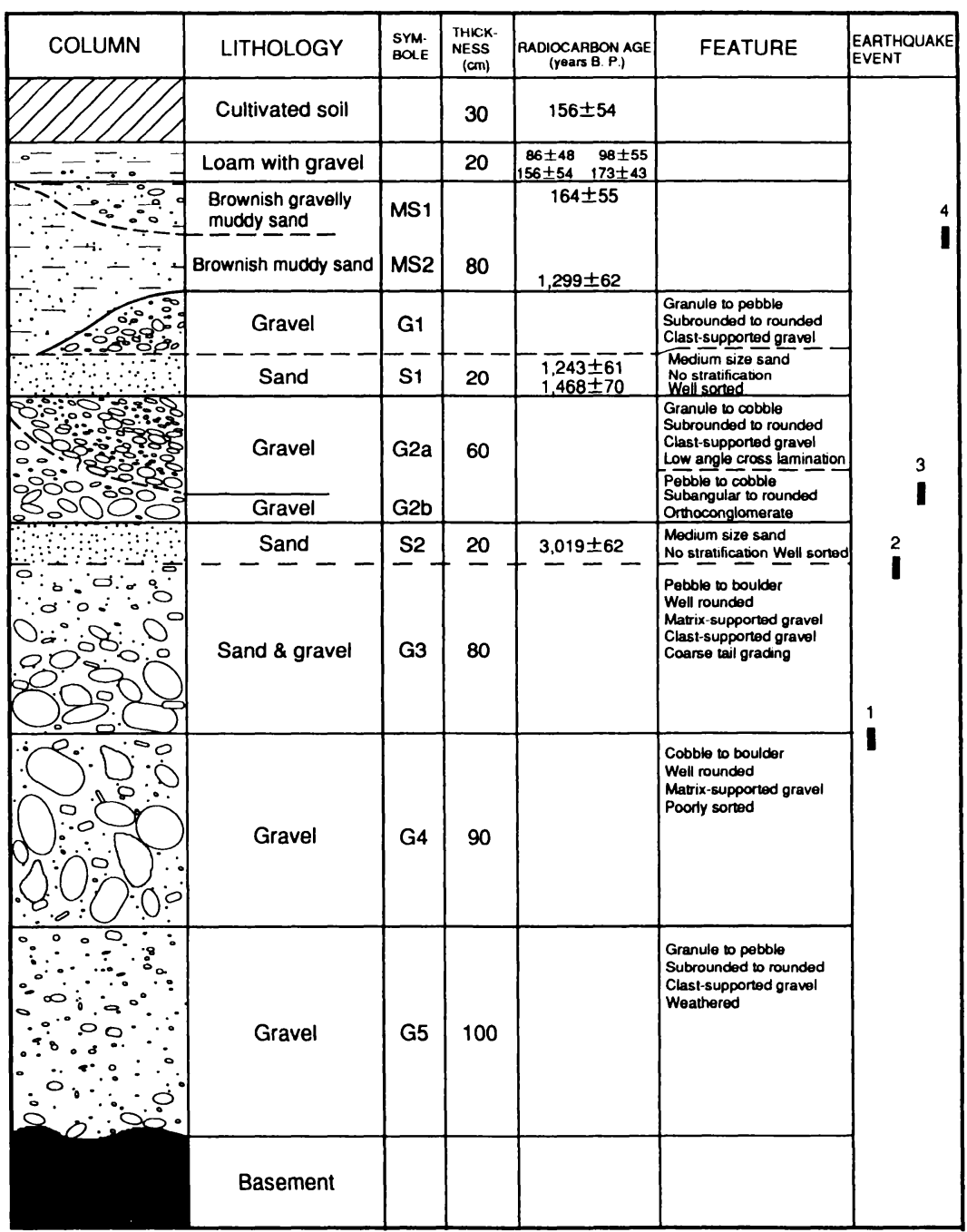

Fig. 8. Schematic geological column of sediments in the trench. Four fault movements since the beginning of gravel deposition were estimated, as shown by thick vertical bars.

4. 䃇層 $(\mathrm{G} 1)$ : 本層は, 花岡岩, 砂岩, 各種の変成岩 を主体とする細〜中礫よりなる，碟は比較的良く円磨さ れており, 棒状〜小判状のものが多い，泥および砂はほ とんど含まれておらず，全体としては砂どうしが接触し 合って堆積しているクラストサポート型の唩層である. また, やや不明瞭ながらプラナー型の斜交層理が認めら れ，見掛け上，東に約 $30^{\circ}$ で傾斜している.

本層はトレンチ東側にレンズ状に認められ，上記のよ うな特徴から, 河川における典型的なポイントバー堆積 物と考えられる.

5. 砂層 $(\mathrm{S} 1)$ ：本層は，無層理で淘汰が非常に良い中 粒砂からなる. 北側法面東側之南側法面に見られ，上位 の䃋層 (G1) や褐色泥質砂層 (MS2) 堆積前むしくは堆積
時に部分的に侵食されている。トレンチ内では最下部が 酸化されて橙〜褐色になっている.

6. 砅層 $(\mathrm{G} 2 \mathrm{a} \cdot \mathrm{G} 2 \mathrm{~b})$ ：本層は，構成砅径および堆積構 造の相違から G2a·G2b の 2 層に分けられる. G2a は, 細〜大砂よりなる低角のプラナー型斜交層理を示すクラ ストサポート型の砂層で, 上部に向かって啋径が小さく なる複数回の堆積のサイクルが認められる. 断層変位の 影響を受けていない部分での啋のファブリックの計測か ら, 現在の吉野川と同じく，ほぼ北から南に向かっての 河川の流れによって堆積したものと考えられる (Fig. 9). G2b は, 無層理塊状の砅層で, G2a に比べ細䃇が少な く, 特に最下部では, 若干大砂が多くなっている. G2a, G2b ともに, 亜角䂰〜円䃯よりなり, 花岡岩, 砂岩, 粘 


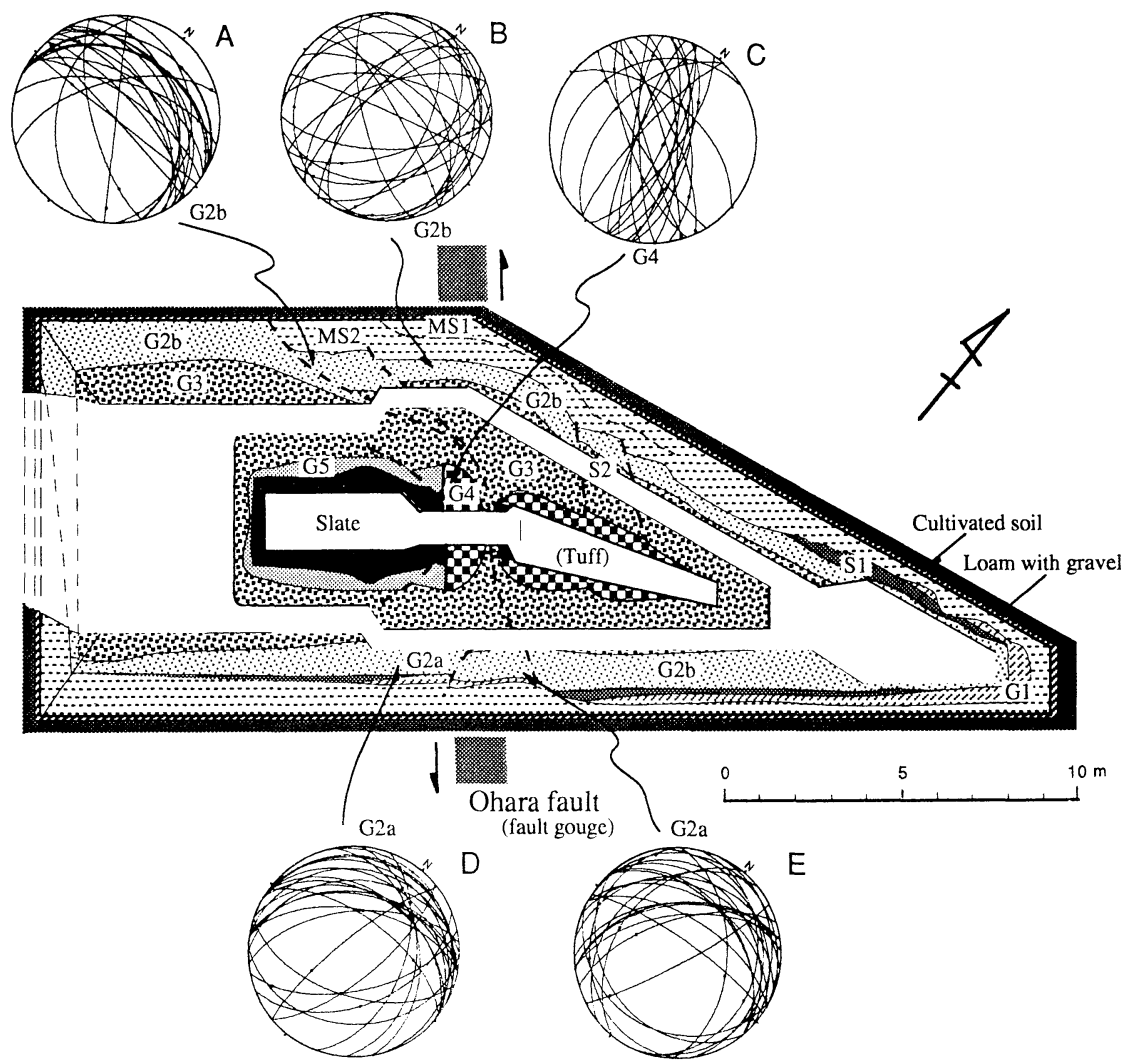

Fig. 9. Gravel fabric in some beds. Planes containig the maximum and the intermediate axes of gravels are projected onto the lower hemisphere using the Schmidt net. Dots show the projections of long axis on the Schmidt net.

板岩, 各種の変成岩類から構成される.

7. 砂層 (S2): 本層は, 最大層厚 $20 \mathrm{~cm}$ の, 淘汰の良 い無層理中粒砂 (S2) よりなるが，一部では碟混じり中 粒砂に層相が変化する. S2 が明瞭に認められるのは北 側法面だけであり，南側法面では G3 との境界が不明瞭 となっている，つまり，下部の砂礫層 $(G 3)$ とは漸移的で 基質となる砂の性状が類似している.

8. 砂碟層 (G3)：本層は，中〜巨碟主体とし，基質は 中粒砂からなるマトリックスサポート型の礫層である. 全体としては砅径が上部に向かって小さくなるコーステ イル級化を示す。本層はその堆積構造から，何らかのイ ベントにより一度に急激に運搬堆積したものと考えられ る.

9. 礫層 $(\mathrm{G} 4)$ ：本層は泥〜巨礫とあらゆる粒径のもの が混在し, 淘汰が非常に悪い。法面においては円磨度の 高い大〜巨碟が突出している，全体としては，基質の泥 〜細碟に支えられたマトリックスサポート型の砶層であ る。また，初生的な粘土之明らかに異なる橙色〜淡褐色 を示す流入粘土が顕著に認められる. トレンチの深部で
は基盤の断層運動の影響によって初生的な堆積構造が消 滅し，断層变位による引きずりにより磁の再配列が顕著 に認められる，砅種は上位の砶層と同じであるが，大〜 巨礫のほとんどは花崗岩である，花崗岩碟の中には，風 化によってややマサ化して脆いものも見られる

10. 礫層 $(\mathrm{G} 5)$ ：本層は，主として円磨度の良い細〜 中礫より構成されるクラストサポート型の礫層である. 全体に酸化作用を著しく被り褐色を呈し，褐鉄鉱および マンガンによる污染が顕著である。トレンチ内では, 基 盤の断層の南東側の粘板岩上にしか認められない．粘板 岩を不整合に覆い, 礫層 (G4) によって覆われている.

11. 基盤：ボーリング調查では, 断層ガウジを挟んで 北東側に凝灰岩, 南西側に粘板岩が期待された. しかし ながら実際は，第四紀層の断層面直下よりも北東側少な くと屯 $30 \mathrm{~cm}$ ほどは顕著に風化した粘板岩が認められ た.

また，最も破砕され細粒化した断層ガウジの部分は， ボーリング調査により推定したように幅約 $1.5 \mathrm{~m}$ 程度 あると考えられる。しかしながら，その断層がウジの部 




Fig. 10. Geological section normal to the Ohara fault as drawn from the bore holes and trench study.

分はトレンチを地表下 $6.3 \mathrm{~m}$ まで掘削しても現われな かった。ボーリング孔 No. 7 において断首ガウジを確認 していることから，地表下約 $7.5 \mathrm{~m}$ 付近に不整合面が 推定され，断層近傍で急激に不整合面が深くなっている ことが考えられる(Fig. 10).

前述した第四紀層も全体として断層面付近で垂れ下が る傾向があり，海上音波探査等で認められる横ずれ断層 の形態 [例えば，今泉・他 (1987)] に類似している。断 層ガウジ全体の走向の直接計測はできなかったが, 断層 ガウジの端とみられる F1 断層を北側法面底面と南側法 面底面をむすぶ走向として計測したところ， N55 ${ }^{\circ} \mathrm{W}$ を 示した。これは, 変位地形抢よび物理探査から推定され る走向と一致している.

南側の粘板岩は層理面に沿って薄い粘土を挟む部分が 多く見られ，全体として節理数む多く，弱く破砕されて いる. 多くの剪断面は層面すべりで，走向は $\mathrm{N} 60 \sim 70^{\circ}$ $\mathrm{W}$, 傾斜は $40 \sim 60^{\circ} \mathrm{N}$ を示す. また, 磁層 (G5) との不整 合面から $20 \sim 60 \mathrm{~cm}$ の範囲は風化が顕著で, 褐色を呈 す.

\section{2 トレンチ内に認められた断原}

Fig. 7 に示すように, トレンチ内に 7 つの断層が認め られた，以下に，それぞれの性状および各地層との関係 を記す。

1. F1 断層: トレンチ最深部において砂層 (G5) を切
り, 砂砂層 (G3) に覆われる断層で, 北側法面では走向 $\mathrm{N}$ $57^{\circ} \mathrm{W}$, 傾斜 $85^{\circ} \mathrm{N}$ を示す. 北側に接する砂層 (G4) は, 法面で見掛け上ほぼ垂直に近い磻の並びを示している. 埋め戻し前に，断層近傍の磁層 (G4) の碟のファブリッ クの計測を行なった結果, 長軸と中間軸のなす面および 長軸そのものが高角で， $\mathrm{N} 45^{\circ} \mathrm{W}$ 方向に集中しているこ とがわかった (Fig. 9).このことは, F1 近傍では, 局所 的な動きとして, F1 断層北側（断層ガウジ側）が落下す るような垂直変位成分が大きかった可能性が示唆され る. 断層面近傍では粘板岩が粘土化し, 風化も顕著であ る.この部分では断層ガウジ内に碟を取り込んだ構造む 見られることから, F1 は砂層 (G5) 堆積後 2 回以上変位 した可能性が強い.

2. F2 断層: F1 断層加ら $\mathrm{N} 65^{\circ} \mathrm{W} / 45^{\circ} \mathrm{N}$ (北側法面) の走向傾斜を示して派生する断層で, 碩層 (G5) を切り, 砂砂層 (G3) の下部にも明瞭な变形を与えている．基盤 の粘板岩中には，明瞭な $1 \sim 1.5 \mathrm{~cm}$ の断層ガウジを挟 む. 法面に見られる形状から，見掛け上北東側が約 80 $\mathrm{cm}$ 低下している. 断層面上のレイクが $17^{\circ} \mathrm{SE}$ を示すこ とから，磷層 (G5) に著しい層厚の変化がなければ，F2 による水平変位量は $2.5 \mathrm{~m}$ 程度と推定される.

3. F3 断層：北側法面では褐色泥質砂層 (MS2) を明 瞭に切断し, 南側法面では褐色泥質砂首 (MS2) を不明瞭 ながら变位させ砅混じり褐色泥質砂層 (MS1) に覆われ 
る. 砂啋混じりロームと耕作土には覆われて変位を与え ていない. 基盤付近では, 磁のファブリック等から, F1 断層より北東側約 $1 \mathrm{~m}$ (断層ガウジからなる幅 $1.5 \mathrm{~m}$ の 破砕帯中の中央よりやや北東側）に位置することがわか る. 北側法面では，地表に向かって徐々に角度を減じな がら上に凸の北傾斜を示し, 南側法面では逆に高角度で 南に傾斜する. 南側法面地表下 $1.5 \mathrm{~m}$ 付近では, $\mathrm{N} 88^{\circ} \mathrm{E} / 65^{\circ} \mathrm{S}$ の走向傾斜を示す. 地層の切断状況とそれ ぞれの走向傾斜等を考慮すると, これらはトレンチを挟 んで連続する断層と判断される.

北側法面の断層北東近傍の碟層 (G2b) の礫のファブ リックを Fig. 9 に示す. 長軸と中間軸のなす面が EW〜 $\mathrm{N} 60^{\circ} \mathrm{W} / 40-70^{\circ} \mathrm{N}$ を示し, 長軸の向きが比較的低角度 である．断層変位の影響を受けていない碩層 (G2b) の ファブリックは，ほぼランダムであることから (Fig. 9 の B), F3 が基盤の断層と大きく斜交し，近傍の砅を引 きずっていることが読み取れる. 長軸が比較的低角度で あることは, 鉛直変位よりも水平変位量の方が著しいこ とを示唆していよう。

以上のように, F3 は, 最新の活動によって生成された と考えられる.

4. F4 断層〜F7 断層：これらの断層は，基盤からの 連続性が確認されていないが, 後述する地層の切断・変 形状況から F3 断層形成期に同時に派生したと考えられ る小断層である.

北側法面では F4, F5, F6, 南側法面に F7 の 4 つの 断層が確認された。 いづれも, 褐色泥質砂層 (MS2) の基 底付近まで切断・変形させている. 北側法面の F4 断層 は, F3 断層より地表下約 $3 \mathrm{~m}$ で分岐している. F3 は褐 色泥質砂首 (MS2) 全体を切断しているが, F4 は褐色泥 質砂層 (MS2) 下底面を変位させ，褐色泥質砂層 (MS2) 内で消隇している，F5，F6 断層はともに, 北側に傾斜す る断層で, F5 断層の走向傾斜は $\mathrm{N} 67^{\circ} \mathrm{W} / 62^{\circ} \mathrm{N}$ である. 基盤付近では，砂碟層 (G3) を見掛け上鉛直方向に約 40 $\mathrm{cm}$ 変位させている.

F7 断層は, 南側法面の F3 断層に対してアンティセ ティックに生じており, 北傾斜で若干上に凸状の形態を 示す.この断層は, 喽層 $(\mathrm{G} 1 \cdot \mathrm{G} 2)$ を切断・変形させ, 砂 磁層 (G3) において F3 断層に収斂している.

以上のように, トレンチ内では断層変位と砂磻層の堆 積が交互に繰り返されており, 古い断層ほど基盤の変位 形態をそのまま地表に現わしていたと思われる.した がって, 新しい断層活動ほど形態が複雑になっている. それは被覆層の厚さと被覆層中の断層形態を明瞭に反映 しており，MANDL (1988) が述べているように，被覆層 が厚くなるに連れて基盤の断層面に対してミ型に雁行配
列を示すような構造を示している (Fig. 7). また, それに 伴い派生する小断層・副次断層も多くなっている.

\section{§ 5. 地原の ${ }^{14} \mathrm{C}$ 年代と大原断厝の活動履歴}

以上のようにトレンチ内で認められた断層変位から, 古町地区における山崎断層系大原断層の活動履歴は, や や不確実なものを含め 4 つのイベントが考えられる (Fig. 8). 以下に古いイベントから述べる.

イベント 1：断層活動時期は, 碩層 (G4) 堆積後, 砂磷 層 (G3) 堆積前である. 認定根拠は, 碩層 (G5) と砂層 (G 4) がF1 断層により明瞭に切断され，互いに接してお り，その上を砂碩層 (G3) に覆われることによる. F1 断 層はこれ以降動いていないものと考えられる.

イベント 2：断層活動時期は砂碩層 (G3) 堆積後, 砂層 (S2) 堆積前である. 認定根拠はF2 断層により砂砂層 (G 3) が切断され, 啋層 (G3) に漸移して堆積している砂層 (S2) に覆われることによる. F2 断層がイベント 1 にと もなって生じたものではないことは, F1 断層が砂碩層 (G3) に覆われるのに対して F2 断層はそれを切ることか ら明かである. しかしながら，F2 断層がその後のイベン ト 3，4によもなって副次的に生じた可能性を否定でき ないため, やや不確実なイベントといえる.

イベント 3：断層活動時期は砂層 (S2) 堆積後, 磉層 $(\mathrm{G}$ 2b) 堆積前である. 認定根拠は, 砂層 (S2) と砅層 (G3) が 撓曲F3 断層に向かって大きく撓曲しているが，南側法 面の啋層 (G2a) の成層した堆積構造に代表されるよう に，砂首 (G2b·G2a) はこの撓曲運動に参加していない ことによる. 北側法面ではF3 断層近傍の啋層 (G2b) 中 の磂の並びと砂層 (S2) の変形が整合することから後述 するイベント 4 と区別しがたいが，碩の再配列は断層の 極く近傍だけであり，碩層 (G2b) は砂層 (S2) と同様の 変形を被っていない. また, 南側法面の砂層 (G2b·G2a) の基盤の断層直上での層厚の増加はイベント 4 とは異 なる断層運動（撓曲）により生じた凹地に厚く堆積した あのと考えられる.

イベント 4：断層活動時期は褐色泥質砂層 (MS2) 堆積 後, 磷混じり褐色泥質砂層 (MS1) 堆積前である. 認定根 拠は, 北側法面で褐色泥質砂層 (MS2) が F3 断層によっ て明瞭に切断されローム層と耕作土に稪われていること と, 南側法面で F3 断層が褐色泥質砂層 (MS2) の基底面 を切断し F7 断層とともに小地溝を形成して，啋混じり 褐色泥質砂層 (MS1) に覆われていることによる. また, 北側法面でも碩混じり褐色泥質砂層 (MS1) は基盤の断 層直上付近に分布していることから，旧地表面である褐 色泥質砂層 (MS2) 最上部が断層運動により, 断層直上付 近で北西一南東を軸とした凹地に落ち込んだことにより 
Table 3. Radiocarbon ages of samples dated by Geochron Laboratories Division in Kruger Enterprises Inc., using an accelerator mass spectrometry (AMS). Libby's half life time of 5570 years was used to calculate the ages.

\begin{tabular}{cllcc}
\hline Sample number & $\begin{array}{c}\text { Lithology } \\
\text { (Symbole) }\end{array}$ & Material & $\begin{array}{c}\text { Krueger Enterprises } \\
\text { Code No. }\end{array}$ & $\begin{array}{c}\text { 14C age } \\
\text { (years B. P.) }\end{array}$ \\
\hline YF-1 & Loam with gravel & Charcoal & GX-18999-AMS & $98 \pm 55$ \\
YF-2 & Sand (S1) & Charcoal & GX-19000-AMS & $1468 \pm 70$ \\
YF-3 & Loam with gravel & Charcoal & GX-19001-AMS & $86 \pm 48$ \\
YF-4 & Loam with gravel & Charcoal & GX-19002-AMS & $173 \pm 43$ \\
YF-5 & Brownish muddy sand & Charcoal & GX-19003-AMS & $1299 \pm 62$ \\
YF-6 & Sand (S1) & Charcoal & GX-19004-AMS & $1243 \pm 61$ \\
YF-8 & Sand (S2) & Charcoal & GX-19006-AMS & $3019 \pm 62$ \\
YF-9 & Brownish muddy sand & Charcoal & GX-19007-AMS & $164 \pm 55$ \\
(MF-10 & Loam with gravel & Charcoal & GX-19008-AMS & $156 \pm 54$ \\
\hline
\end{tabular}

堆積した可能性が強い.なお，F4〜F6 断層は褐色泥質 砂層（MS2）の基底面をわずかながら変位させているこ とから，このイベントの際に副次的に生じた断層である と考えられる.

これらのイベントの年代を制約するために, Fig. 7 に 示すようないくつかの地層から検出された炭化木片の年 代值を, 米国クルーガーエンタープライズ社に依頼し, 加速器質量分析計を用いた ${ }^{14} \mathrm{C}$ 年代測定法により求め た. 測定結果を Table 3 に示す.これにより, 最近の 2 回の活動年代に制約を与えることができた.

イベント 3：3019 62 y. B. P. の年代を示す砂層 (S2) を大きく撓曲させ，その後に堆積した砅層 (G2a, G2b) に覆われている，啋層 (G2a，G2b) の年代は不明である が, その上位の砂層 (S1) の年代が $1243 \pm 61$ y. B. P. と $1468 \pm 70$ y. B. P. を示すことから, 約 3000 年前〜 1500 年前に限定される.

イベント 4 (最新活動時期)：活動時期は, $1299 \pm 62 \mathrm{y}$. B. P. の年代值を示す褐色泥質砂 (MS2) 堆積後, 最上部 が $164 \pm 55$ y. B. P. を示す褐色磻質泥質砂 (MS1) 堆積前 である．褐色泥質砂 (MS2) より下位の砂層 (S1) む 1243 \pm 61 y. B. P. と $1468 \pm 70$ y. B. P. を示すことから, 大原 断層の最新活動時期は地層年代からは約 1200 年前〜 150 年前と制約される.

宇佐美 (1987) は, 山崎断層系分布域周辺に被害を与 えた歴史地震として次のものを挙げている.

1. 868 年播磨地震: $M \geqq 7.0$

2. 1711 年伯耆地域の地震: $M=6 \frac{1}{4}$

3. 1864 年播磨・丹波地域の地震： $M=61 / 4$

4. 1916 年神戸地域の地震: $M=6.1$

これらのうち, 1864 年と 1916 年の地震については 比較的新しく資料の豊富な地震であり, 地震規模がそれ ほど大きくないことと震源が兵庫県東部地域であること
がわかっているので, 大原断層の活動には該当しない.

1711 年の地震は, 推定される震源域が大原断層から かなり西方に離れていることと, この地震が 1943 年の 鳥取地震の起こり方に似ていることなどの指摘［武者 (1941〜1943)] から, 大原断層の活動による地震とは考 えにくい.

西暦 868 年の播磨地震は, 岡田・他 (1987) によって 同じ山崎断層系の安富断層の最新活動による可能性が指 摘されている。しかしながら，この地震は宇佐美 (1987) によって, $M \geqq 7.0$ とされており, 断層長 $18 \mathrm{~km}$ の安富 断層の単独の破壊だけでは説明困難であるように思われ る.

以上の理由より, 山崎断層系大原断層の最新活動時期 は, 現在の歴史史料から考えた場合, 安富断層と同様に 868 年の播磨地震である可能性が最も高い.

したがって最新活動時期が西暦 868 年の播磨地震に 一致すると考えると, 一つ前のイベント 3 との活動間嵒 は, Fig. 11 に示すように約 400 年以上 1900 年以下と いうことになる。

上述したような 4 回のイベントの平均活動間隔を求 めるにはトレンチ下部の砅層 (G4) の堆積年代を求める 必要があるが, 今回の調査では碩層 (G4) から炭素試料 を検出することができなかった，しかしながら，地形面 としては現河床との比高がわずかであり，完新世［第四 紀学会 (1987)］もしくはそれ以前の地形面の可能性が高 いといえる. 仮に完新世とした場合，1万年に 4 回の活 動があったことになり, 平均再来期間は 2500 年程度と なる，完新世以前の古い地形面とみなすと, 平均再来期 間は 2500 年より大きく見積られるが，前述した最新活 動時期とその 1 つ前の活動時期の間隔が最大でも約 1900 年であることから, 活動間隔の大きなゆらぎを考 虑しなくてはならない.

\section{§ 6. 山崎断層系のセグメンテーションと 868 年播 磨地震}

Fig. 11 に, 今回のトレンチ調査結果と岡田・他 (1987) による山崎断層系安富断層のトレンチ調查結果 を比較した. 岡田・他 (1987) は, 5560 年前以降やや不 確実なものを含め 3 回の断層運動を検出している.これ は, 今回のトレンチ調查結果の 1 万年に 4 回程度の活動 と大雑把には一致している. 最新活動時期については, 岡田・他 (1987) は 750 1170 年前という ${ }^{14} \mathrm{C}$ 年代によ る制約から西暦 868 年の播磨地震の可能性を示唆して いる. 今回調査した大原断層でも，前述のように 1200 年前〜150 年前の活動が示唆され, 歴史記録に対応させ るならば，岡田・他 (1987) の安富断層と同様に播磨地 


\section{Ohara fault $\quad$ Yasutomi fault}

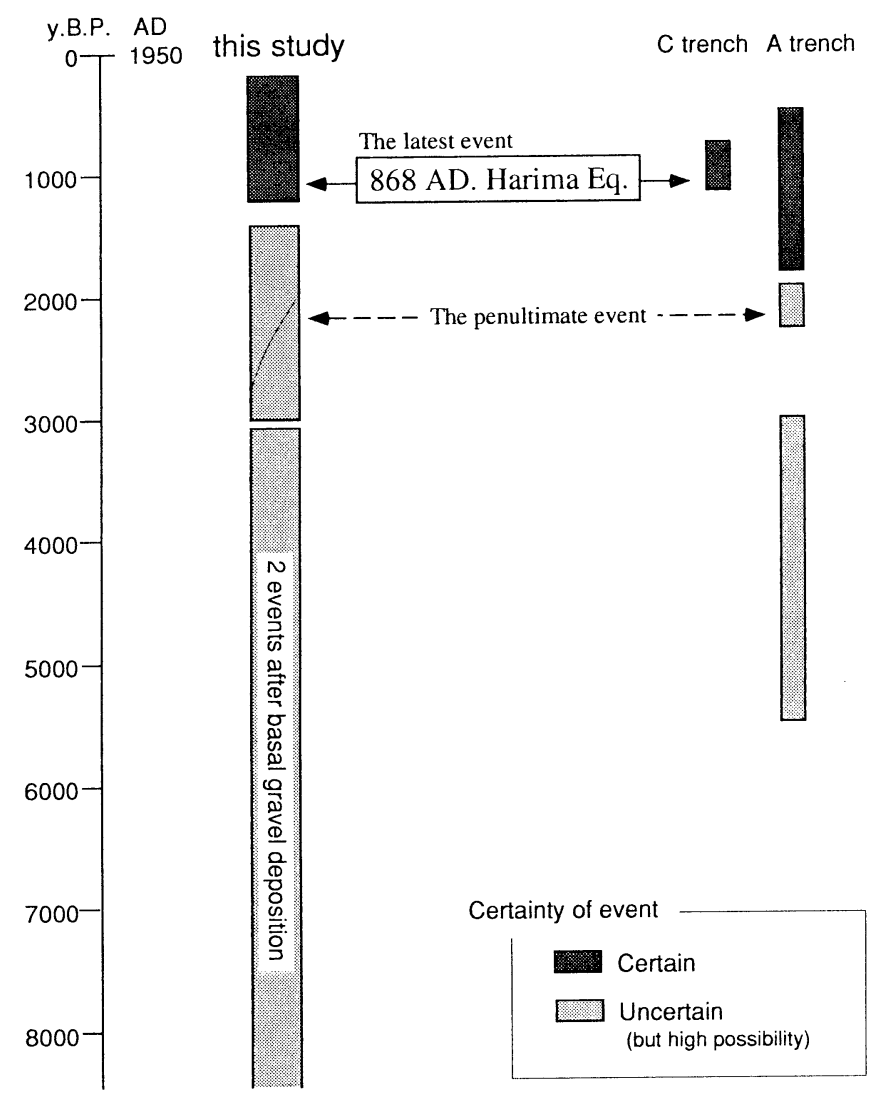

Fig. 11. Comparison of the estimated ranges of faulting events between the Ohara fault (this study) and the Yasutomi fault (OKADA et al., 1987). The fault movements of the two faults roughly coincide. The latest faulting event of the faults is likely to correspond to the 868 Harima Earthquake.

震で変位した可能性が高いことがわかった.

最新活動時期より 1 つ前の活動については, 岡田・他 (1987) の安富断層では不確実ながら 1900２500 年前 の断層運動の可能性を述べた.これについても, 今回調 查した大原断層では堆積物の ${ }^{14} \mathrm{C}$ 年代から $1500 \sim 3000$ 年前の活動が認められ, 広範囲の年代值ではあるがほぼ 一致している.

このように, 大原断層と安富断層の活動は大雑把には 一致しており，地質学的なタイムスケールでほぼ同時期 に活動していることがわかった，大原断層と安富断層の 間には土万断層が存在するが，この土万断層をスキップ して活動するとみるには無理があるため, 山崎断層系の 大半を構成するこれら 3 つの断層セグメントは, 互いに 相互作用を及ぼし, 同様な時期に活動しているものと考 えられる.つまり, 山崎断層系の中でも大原断層, 土方 断層, 安富断層は同時に動くか, 時間差をとあなったマ
ルチプルイベントをおこした可能性が強いといえる.

なお, 最新活動時期と考えられる西暦 868 年の播磨地 震に関しては史料の解析により, $M \geqq 7.0$ であると推定 されている [宇佐美 (1987)]. 松田 (1975) の地震の規模 と断層破壊長に関する経験式を考慮すると, $M \geqq 7.0$ の 地震を発生させるためには少なくとも $20 \mathrm{~km}$ 以上の断 層長を考えるのが妥当である. 安富断層は断層長が 18 $\mathrm{km}$ で, 単独で播磨地震程度の地震を発生させるにはや や無理があり, 大原断層から安富断層までを一括で破壊 させた場合の方が，地震の規模を矛盾なく説明できる. したがって播磨地震では，時間差をともなったマルチプ ルイベントと考えるよりも同時に動いた可能性の方が強 い. この場合, 松田 (1975) の経験式を適用すると $M=$ 7.8 となり, かなり大きな規模の地震となる. この地震 規模は, 播磨地域の被害からするとやや大き過ぎるとも 考えられるが，震央を宇佐美 (1987) が推定した位置よ 
りあ山崎断層側に位置づければ，説明できるであろう．

\section{§7. おわりに}

山崎断層系大原断首の古町地区における詳細な断首位 置と最近の活動史を明らかにするために, 電気探査, ボーリング・トレンチ調查を実施し，以下のような点が 明らかになった。

1）古町地区における大原断層は，中古生界の酸性疑 灰岩（北側）之黒色粘板岩（南側）の地質境界となって おり, 高密度な地表の電気探查から比抵抗值にも顕著な 差異を生じさせていることがわかった。

2）大原断層の最新活動時期は, 地首の年代測定から は150〜1200 年前と制約された。ささらに，歴史上の被 害地震記録から西暦 868 年の播磨地震を引き起こした 可能性力強い.

3）最新活動時期の 1 つ前の活動は，地層の年代測定 からは 1500〜3000 年前と制約された.これにより, 最 新活動時期が西暦 868 年の播磨地震であるとすると, 一 つ前のイベントとの活動間隔は, 約 400 年以上 1900 年 以下ということになる。

4）大原断層の最近の活動は，多く見積っても 1 万年 に 4 回程度と推定され, 平均活動間隔は約 2500 年前後 と考えられる.これは, 最新活動時期と 1 つ前の活動の 間隔よりやや長く, 活動周期にゆらぎがあるものと考え られる.

5) 今回の調查結果と岡田・他 (1987) の安富断層の 結果を比較検討すると, 平均活動間隔や最近 2 回の活動 時期が似通っており，山崎断層系の中でも大原断層，土 方断層, 安富断層は, 同時に動くか, むしくは時間差を ともなったマルチプルイベントをおこすような関係にあ ると考えられる.

\section{謝 辞}

本研究を進めるにあたり, 原子力発電技術機構の垣見 俊弘博士には大変有益なご意見をいただいた，また，東 京大学理学部の池田安隆博士之匿名查読者, ならびに担 当編集委員の嶋本利彦教授には原稿の不備な点をご指摘 頂いた，電気探查の実施に際しては，(株)日本地殼調查 の城森明氏, 九州大学工学部の藤光康宏博士, (財) 電力
中央研究所の阿部信太郎博士の御協力を得た。ボーリン グ・トレンチ調査では森本義見氏の水田をお借りすると ともに, 浅尾善郎氏を始め, 大原町町役場の方々に多㞳 にわたり暖かくご援助していただいた。調查全般にあ たっては, 長江倫好氏と中山芳樹氏を中心とする (株)日 本パブリックエンジニアリングの方々にご協力いただい た。トレンチ法面の観察および被覆層の変形に関して は, (財)電力中央研究所の上田圭一氏との議論が有益で あった. ここに記して以上の方々に心から感謝の意を表 する.

\section{文献}

福井謙三, 1981, 山崎断層系の変位地形, 地理学評論, 54, 196-213.

池辺展生・藤田和夫 - 松田時彦・岡田篤正, 1969, 山崎 断層は横ずれ生動する, 日本地質学会西日本例会講 演.

今泉俊文・島崎邦彦・宮武 隆 - 中田 高 - 岡村 真 千田 昇・貝塚爽平・岩田孝行・神谷真一郎・畑中雄 樹・橋田俊彦, 1987, 三浦半島南東部沖金田湾におけ る海底活断層の発見 (新称：金田湾断層), 活断首研 究, 4, 28-36.

活断層研究会, 1991, 新編日本の活断層一分布之資料, 東京大学出版会, $363 \mathrm{pp}$.

神戸信和・広川 治, 1963，5 万分の 1 地質図幅「佐用」 および同説明書, 地質調査所, $29 \mathrm{pp}$.

楠 建一郎 - 本荘静光, 1990, 活断層之物理探査, 物理 探查, 43, 386-401.

MandL, G., 1988, Mechanics of Tectonic Faulting, Elsevier, $407 \mathrm{pp}$.

松田時彦，1975, 活断層から発生する地震の規模と周期 について, 地震 2, 28, 269-283.

松田時彦・岡田篤正, 1968, 活断層, 第四紀研究, 7, 188-199.

武者金吉, $1941 ４ 3$ ，増訂大日本地震史料，第 1 第 3 巻, 文部省震災予防評議会.

日本第四紀学会, 1987, 日本第四紀地図, 東京大学出版 会, $119 \mathrm{pp}$.

岡田篤正・安藤雅孝・佃 為成, 1987, 山崎断層系安富 断層のトレンチ調査, 地学雑誌, 96, 81-97.

志村 馨, 1964, 電気探査法, 昭晃堂, $182 \mathrm{pp}$.

内田利弘・小川康雄・村上 裕, 1984 , 姫之湯断層にお ける地下レーダー法調査, 物理探査学会昭和 59 年春 季講演予稿集, 87-88.

宇佐美龍夫, 1987 , 新編日本被害地震総覧, 東京大学出 版, $453 \mathrm{pp}$. 